\title{
From ideas to action: A review of implementing HELP principles in river basins with limited resources and capacity $\#$
}

\author{
Declan Hearne $^{1 *}$, Ruth Gamboa ${ }^{2}$ and Verna Marie Monsanto ${ }^{2}$ \\ ${ }^{1}$ HELP Davao, 248 Arayat St., Central Park Phase I, Bangkal, Davao City, Philippines \\ ${ }^{2}$ The University of Philippines, Davao, Mindanao, Philippines
}

\begin{abstract}
Davao City is overlapped by 8 watersheds all flowing into the Davao Gulf. These watersheds exemplify a range of cultural, environmental and economic stresses from the continual conversion of natural habitat for agricultural, urban, and industrial uses. These changes and their consequent pressures have not gone unnoticed and have surfaced through various channels into the political and public arenas. However, despite the awareness and actions from various sectoral initiatives, there is continual deterioration of trends across the ecosystems.

Hydrology for Environment, Life and Policy (HELP) is a global initiative which encourages policy makers, water managers, scientists, and end-users to work together within a field-oriented context to closely integrate science into government policies and management strategies. Through Davao City's participation in the HELP Network, the management of watersheds and water has improved not through the acquisition of additional external funds but by the increase in opportunity for dialogue between 'water-related' communities, which resulted to enhanced stakeholder understanding of issues and increased technical capacity of all involved.

This paper demonstrates how the HELP principles can be applied in basins with limited resources and how these can positively influence the attitudes and behaviour of stakeholders. It highlights how HELP can act as a catalyst to motivate learning, engage competing sectors, and build collaboration to create science-backed frameworks for good water governance.
\end{abstract}

Keywords: HELP, watershed, ecosystems, twinning, community management, empowerment, good governance, collaboration, conflict

\section{Acronyms}

CRS : Catholic Relief Service

DCWD : Davao City Water District

DCW : Davao City Watersheds

DENR : Department of the Environment and National

Resources

DRCCC : Davao River Conservation Committee

EO : Executive Order

HELP : Hydrology Environment Life and Policy

IUCN : International Union for the Conservation of Nature

IRR : Implementing Rules and Regulations

PBGEA : Philippine Banana Growers and Export Agency

PCEEM : People Collaborating for Environmental and Economic Management

RCU : Regional Coordinating Unit

SMART : Water Systems Management and low cost Agricultural Responsive Technologies

UNESCO : United Nations Education, Scientific and Cultural Organisation

VSO : Volunteer Service Overseas
Revised paper. Originally presented at the symposium 'HELP in Action: Local Solutions to Global Water Problems - Lessons from the South' which was held at the Emperor's Palace, Johannesburg, South Africa from 4 to 9 November 2007.

* To whom all correspondence should be addressed.

䰷 +63 82 2984203; fax: +63 82 2984203; e-mail:dhfotography@gmail.com; declan@surfaidinternational.org

\section{Introduction}

Across the Philippines, issues surrounding watershed management are ecologically, socially, economically, and politically complex. This complexity, coupled with limited understanding of watershed management issues including land use change and development trends, and the unpredictability of many natural (Taylor et al., 2006) and human-induced events, reduce the reliability of management decisions and development outcomes (Catacutan, 2006).

Through the years, land conversion and subsequent environmental degradation has been increasingly documented. Davao City has also seen a steady growth of individuals and organisations advocating for positive changes and affirmative actions towards sustainable use of resources. Prior to the participation in the UNESCO IHP-HELP Network, water related issues and pressures facing the city's watersheds were already topical in political and public spheres and were commonly making it to the front pages of local media. However, despite the awareness, limited progress had ensued. Limited collaboration among sectors and fragmented management and policies were further undermined by a lack scientific data to guide options and decisions. In these circumstances, the potential economic and environmental services from good collaborative management of the natural resources remained under utilised.

The UNESCO IHP-HELP Network provided a framework to fill this gap. Through participation in this global network of watersheds, Davao adopted the HELP principle to use hydrological knowledge to bring together different sectors and formulate sound solutions to water-related issues. 
At the core of the process was raising participation and ownership by initiating discussions among different and often competing sectors. Strong collaboration, a user-driven structure, sound leadership, and continual recognition of successes are the adopted strategies that successfully contributed towards raising participation and ownership. These are later expanded upon as key drivers in HELP Davao.

Over a three-year period, the management of water in Davao has progressed from sectoral, and often contradictory, into cooperation and integration, even without the financial resources that are usually requisite for progressive implementation of water management. The process for achieving this paradigm shift had four key steps:

- Streamlining and integration

- Sharing knowledge

- Expanding technical capacities

- Using science to guide legal frameworks.

Prior projects and voluntary initiatives provided valuable lessons and encouragement to stakeholders, indicating that progress could be achieved with minimal resources. With the HELP Network as a catalyst to build upon and sustain earlier efforts, the many challenges presented opportunities to innovate, learn, and share experiences

\section{The Davao HELP basin}

According to local historians, the name Davao came from the aboriginal Bagobo word davoh, which referred to Davao River, an essential lifeline for the tribe. To the Bagobo tribe, the word davoh also means a place 'beyond the high grounds', alluding to the settlements located at the mouth of the Davao River, where they bartered their forest goods.

Today that settlement has grown to population of 1.4 million and covers a land area of $2444 \mathrm{~km}^{2}$ making it the largest city in the Philippines in terms of land area (CPDO, 2000).

Davao City has a diverse array of natural and man-made landscapes. The ecosystems range from upland mountainous forests that include small pockets of primary forests, secondary forests and mixed scales of agriculture. In the low lands most natural wetlands have been converted to rice with dryer landscape developed for plantation or fruit orchards. These mixed landscapes slowly gives way to peri-urban areas before entering into the City proper. Along the coastal zone of the Davao Gulf coconut predominates and small stretches of mangrove remain.

Under current land-use classifications $50 \%$ is timberland or forest. Industrial logging ended in Davao by the early 1980s. By then, other plantations such as for bananas had already been established (Tiu, 2005). Agriculture, including banana, pineapple, coffee, mango, durian and coconut plantations, accounts for $43 \%$ of the land area, all contributing to make agriculture the largest economic sector in Davao. Residential, institutional, commercial, and industrial areas cover the remaining $7 \%$. Under the approved Land Use Plan built-up and settlement area will cover $15 \%$ of the total area while agricultural will be maximised to $68 \%$. Only the remaining $18 \%$ will be devoted to forest and conservation (CPDO, 2000)

The land cover of Davao City is of steepest relief to the north and west which gradually flattens as the altitude drops near 3 $000 \mathrm{~m}$ to the sea level at the south. The City is serviced by 8 major watersheds (Fig. 1). Of the 8 watersheds, only the Davao, Lasang, and Tuganay Rivers have substantial upstream land areas outside the jurisdiction of Davao City. Both the upstream

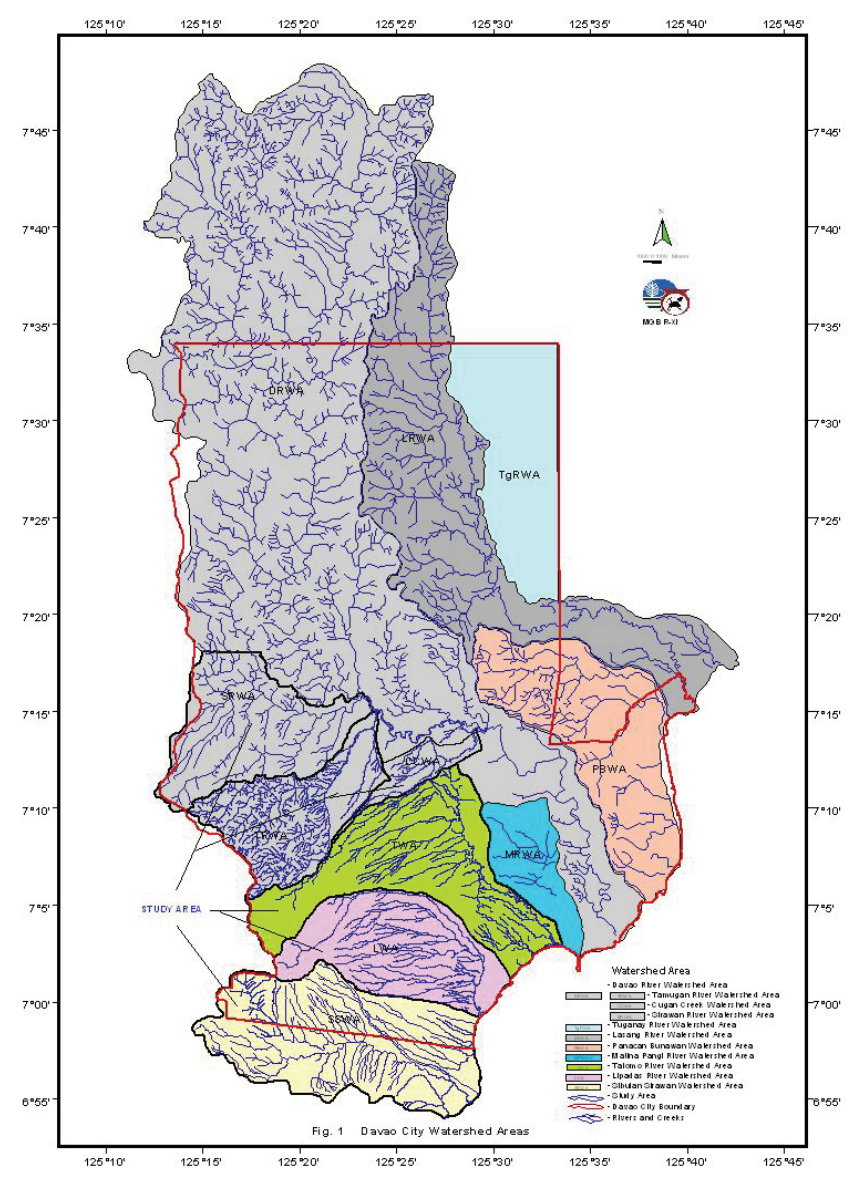

Figure 1

Map of Davao's 8 main Watersheds

areas of Lasang and Tuganay are estimated to have relatively low land-use pressures and therefore pose limited risks to the downstream flows of the rivers. However, the upstream area of the Davao River has greater development pressures and thus has the potential to adversely affect downstream communities. With a population growth of $2.83 \%$, Davao City will become increasingly dependent on healthy and functioning watersheds to sustain urban populations (Evans, 2002).

\section{Context}

\section{Prior to HELP networking: Policy and management initiatives}

Even with limited monitoring data the impacts and trends in ecosystems across the Philippines are evidently not positive (Cruz and Cruz, 1990; Catacutan, 2006; Gamboa, 2006). The policies and institutions within the Philippines are generally better established for managing water supply for the demands of the various drivers (population, industrial, agricultural, irrigation, etc.) as opposed to managing water in an integrated sustainable approach. With this, contradictions and conflicts in rules and roles are inevitable as departments and organisations evolved their mandates and policies in isolation (Evans, 2003).

At the national level, the National Water Resources Board (NWRB) was established in order to coordinate the use of water for the different purposes, but the lack of reliable data on present water resources and water use, coupled with conflicting depart- 
ment mandates hampered the progress and the effectiveness of the NWRB. The absence of an NWRB field office in Davao furthers the weakness of the organisation's capacity to coordinate water use in Davao's watersheds (Evans, 2003).

In the absence of national government actions, a number of local initiatives started building awareness and capacities in the different watersheds of Davao City. Major efforts in development of integrated water resource management (IWRM) had been the focus in the Talomo - Lipadas watershed, the source of major aquifers that provide $96 \%$ of the Davao City Water District's (DCWD) regulated drinking water supply. But since DCWD only serves $56 \%$ of the total population of the City, large populations across the watersheds continue to be unregulated for water supply. Being the largest watershed, Davao River plays a key role in ensuring water for much of the remaining $44 \%$ of the population and is critical for other factors including food production and other ecological services.

The first formal organisational initiative was the PhilippinesCanadian Environmental and Economic Management Project (now People Collaborating for Environmental and Economic Management), PCEEM, commenced in 1998 to help improve the health of the Talomo - Lipadas watershed by building collaborative and integrated governance supported by continuous capacity enhancement. Similarly the multi-sectoral Davao River Conservation Coordinating Committee (DRCCC), was formed in 1999 through City Executive Order 29. The central role of the committee was to help conserve the Davao River through the promotion of projects to rehabilitate and enhance the watershed. The early efforts were followed by the EcoGov project which is assisting the city in formulating watershed management plans for Davao River and Talomo-Lipadas watersheds, and the development of Mindanao Watershed Framework led by the Mindanao Economic Development Council.

It is noteworthy that many of the actions and plans were done through partnerships and volunteerism. The development of the Davao River Code, the Davao River Management Plan, the recommendations on hydrological monitoring needs, studies on sustainable livelihoods approach for Barangay, community based planning workshop and the GIS database are outputs achieved largely through volunteerism.

\section{Joining the HELP network Davao}

The traditional separation between water resource managers, end-users (be it private or public), and scientific communities predominated in Davao, where the research agenda is isolated by lack of proven usefulness and water policy is made most of the times independent of scientific knowledge. Only few organisations have demonstrated an understanding of the relationship between healthy functioning watersheds and the provision of services such as clean drinking water and water for industrial and agricultural uses.

In 2003 Catholic Relief Services (CRS), recognising that the development of IWRM can play a vital role in poverty alleviation in developing countries (Shepherd, 2004), sought to support local watershed initiatives. The HELP approach was identified as a potential driver to bring local actors together and in January 2004 a proposal for inclusion of the Davao River basin was submitted to the international HELP network of river basins under UNESCO. In June 2004 the proposal was approved and the Davao River basin was classified as an Operational HELP Basin, defined as 'one which is implementing the HELP philosophy and is involving most HELP stakeholders in watershed management.'

\section{Drivers for participation and ownership of HELP}

In early 2005 a series of CRS-led workshops socialised the HELP concepts to key local actors and consensus was reached to use the HELP Network as a driver for integration of existing initiatives. The complexity of issues and the limited resources available signified a daunting task to develop integrated management for all 8 watersheds. With many of the hard technical issues remaining to be tackled, the HELP Evaluation Committee in 2004 highlighted the soft practices as the key strengths for developing integrated management approaches in the Davao River basins (Khan, 2004). The Davao HELP network looked to build on these strengths and through the adoption and constant reinforcement of four strategic drivers, strong participation and ownership were enabled.

\section{- Collaboration}

The Davao Network's core strategy was constant consultation and identification of areas of common interests of stakeholders, including end users, researchers and land and water managers, instead of conflict issues. The key for sustaining the engagement of competing sectors was to employ science to address water- related issues.

Recognising the main local actors for designing and implementing water resource protection was critical for ensuring any collaboration effort can effect lasting change. Strong collaboration of researchers and interest groups with local councillors and government officials was therefore the backbone to the success of implementing HELP philosophy in Davao.

This multi- sectoral participation promoted a more balanced a view of competing interests. Participating politicians better understood the societal costs of not establishing environmental protection and they in turn became environmental champions within Davao HELP network leading the drafting of science based water laws and ordinances.

The science-based options over ridged singular solutions opened the often polarised stance of industry, researchers and water managers alike. The dynamic science based policies helped to unlock previously held positions, breaking old paradigms and allowed greater exploration of the benefits from collaborative management.

\section{- User-driven Structure}

The Davao network was formed on a voluntary basis to build better collaboration across the watersheds. The direction of the network was continually set and refined through workshops attended by a wide range of stakeholders. It was these stakeholders who set the user-driven agenda for actions on water-related issues. Regular meetings were hosted by different organisations in rotation. With actions and training themes being identified by the network members, transparency into the capabilities and interests of individual institutions is ensured, and participation and sense of ownership are continually fostered.

This user-driven structure of the project team helped to broaden the array of issues identified for actions but also enabled closer reflection of specific issues facing individual communities and businesses across the watersheds. This structure allowed the local conditions and specific needs of individual communities to be raised into the forums and arenas of policy and decision makers. 


\section{- Leadership}

Recognising that process change is slow and restructuring of institutional arrangement is often a continuing process, strong leadership is required to ensure that the focus remains on the positive elements of HELP and to provide vision in balancing decisions as a range of competing interests come sharply into focus. This leadership however must be focused on facilitating learnings from the end users and supporting local champions who drive better understanding of field realities.

In the network, local stakeholders were encouraged take leadership roles in raising pertinent issues which help direct policy makers in the formulation of local laws. These local stakeholders raise pertinent issues and drive these issues forward into the realm of all actors relevant to water and particularly into the forums of decision makers.

The role of local facilitators therefore plays a critical role in providing continued stimulus to keep actions focused on real issues. In many ways the Davao HELP network has become the link for decision makers to meet with local champions and community leaders.

\section{- Recognition}

As the Davao HELP network is functioning without formal institutional arrangements, it is completely dependent on the voluntary participation of stakeholders. Without financial return, status rewards is seen as an important driver for sustaining participation. The high profile status of involvement with a UNESCO-led network was an important stimulus for participation from the outset. The visits from the HELP Regional Coordinating Unit (RCU) acted as milestones in the progress of the Network and generated broad scale interests through workshops, trainings, public forms and media coverage all leading to increasing interest and support for the network.

Many initiatives of individual stakeholders were noted to be having positive impacts but were not receiving due recognition. The network acts as an arena for the bonding of individual efforts and building appreciation for efforts of all stakeholders across DRW's at various levels, locally and internationally.

The HELP Davao network has consistently pushed these four drivers in dialogues, planning and implementation activities. This helped build a level platform where activities, meeting and network tasks are distributed among the actors in accordance with their capabilities and resources. The resulting impact of these combined efforts was the creation of a vehicle to drive a forward shift from sectoral management to cooperation and integration of water resource management.

\section{Realising the HELP philosophy: The Davao formula}

The participation in the HELP network came at a time when existing initiatives were at defining points for funding or organisational reasons. While key decision makers and managers in the local and national government agencies were supportive of an integrated approach towards watershed management, cohesion between the actors across the 8 watersheds was inadequate. The HELP network, its philosophy and aims, provided a timely framework to consolidate move forward previous efforts.

In this section we explore the formula adopted in Davao by looking at the four key sequential stages from raising consensus, participation, action and impacts. In realising the HELP philosophy with limited resource we also reflect on the limitations of the Davao formula.

\section{Streamlining and integration: Reaching consensus}

With many different organisations mandated to perform various tasks to monitor the environment, a very complicated organisational environment existed in Davao. There is extensive baseline information available in the basin. References include Davao River Situational Report, Asian Geodyne Study, diverse aquifer studies (DCWD, 1999) and Hydrological Monitoring Conditions and Recommendations (Evans, 2003). Rainfall data are available from the airport over 40 years, from the Philippine Coconut Authority (PCA) for over 25 years and from Davao Fruits for over 15 years. River discharge data between 1984 to 1990 are existing, as are water quality data which are monitored at 8 stations 4 to 5 times per year. Local universities have also conducted studies on heavy metals. The Bureau of Soils and Water Management and the Department of Agriculture collect data on physical attributes of soils. GIS land-based maps have been produced by the City Planning Office with early assistance from the DRCCC and VSO.

With no one system or an agency with the overall responsibility for IWRM, interventions were inadequate and individual technical solutions remained insufficient. The Hydrological Monitoring Conditions and Recommendations (2003) also suggested that the data collected were insufficient to calculate the water balance of the catchment, design river structures and analyse the impacts of land-use changes on water quality and quantity. All of which are factors that have a significant impact upon health and economic losses due to wasted investments, local drought, flooding, erosion and loss of livelihoods.

Using the four key drivers for participation mentioned, actors from various sectors were brought together in discussion tables to identify the amount of data already available. Enumeration of the existing data provided a safe starting point for raising the consensus of the need for streamlining and integration of data and actors.

How the consensus was achieved is critical. For the Davao HELP network, it involved numerous participative workshops which were process rather than goal driven, and where mandates were identified, and even disagreements were aired. Many of the data collection agencies lack the resources required to monitor all their mandated variables, let alone the capacity to manage the dynamic databases. Typically, once data is shared it is open to scrutiny. The HELP network provided an outlet where data could be shared for constructive feedback rather than criticism of failures. The creation of this safe environment for sharing of data was essential and was only made possible through constant consultations which had improved inter-agency relationships. A notable impact from these early consultations was a sense of progress among a range of actors who previously had seen 'no common ground.' The cohesion among the stakeholders slowly enabled debates to progress more productively.

\section{Sharing Knowledge: Raising participation}

The next step was to move the common issues from the discussion tables towards participatory action. This required clarification of roles for collection and management of data. It also required initiating strategies to share the burden of analysis of converting scientific data into practical information for end users and policy makers. 
To gain awareness on how to apply scientific knowledge to studies, policies, and approaches, Davao twinned with the Murrumbidgee 'HELP Demonstrational' River Basin in Australia. Limited funding from the INBO (International Network of Basin Organisations) enabled cross visits under the INBO TWINBAS$\mathrm{IN}^{\mathrm{XN}}$ Project. These cross-visits were highly appreciated by the lead government agencies and this had been reflected in their principal participation in preparing for the visits.

A significant outcome from the twinning was the renewed 'openness' and participation of the Davao City Water District (DCWD). While the 44 abstraction wells operated by the DCWD have remained within the Philippine National Standards for Drinking Water, in depth observations revealed that land-use changes and other human activities within the vicinity of the wells and in the recharge areas are enough to raise serious concerns. A HELP-led Land and Water Workshop for field officers, plantation managers, and marginal farmers enabled the participants to appreciate the risks of pollutants to drinking water. As a result, buffer zones near water courses have been established and as the pressures on recharge areas increase, the importance for understanding the pathways of pollutant is being prioritised by the DCWD. The DCWD is shifting focus from monitoring static quality and quantity limits, towards a mapping of trends for early warning signals that will allow for more time for mitigation measures.

With increased participation, the academe was encouraged to take the lead in conducting researches, coordinating trainings and workshops to help address the technical gaps in watershed governance in the city as well as the wider Mindanao region. A CRS funded partnership with PCEEM enabled the HELP Network to assist local communities develop best agricultural practices and community based water monitoring programs. These marginalised communities were subsequent hosts for cross visits.

This CRS- PCEEM partnership provided a channel for participative pooling of resources and expertise in shaping the Davao City Integrated Watershed Management Framework. The participation of various stakeholders indicated the shift from sectoral outlook towards integration. Indirect impacts and behavioural changes were also beginning to be witnessed in policy debates in the city council chambers (Bais, 2006). These subtle changes were brought about as managers and policy makers exercise their scientific and practical learnings into their everyday roles in governance and management of water resources, and later materialised policies with greater scientific rigor.

\section{Expanding technical capacities: Raising action}

The next step in the implementation of the HELP philosophy was the expansion of successful projects and furthering of technical capacities.

As available data have been pooled, and participation of various stakeholders in the determination of research agenda has been achieved, scientific outcomes started to become the basis for further researches, with the ultimate aim of providing sound scientific basis for management decisions.

One of the first expanded land-use based analysis in any of the DCWs was made in the Talomo Lipadas watersheds (TLW). The PCEEM commissioned study on terrain analysis of a subcatchment of this main source of groundwater supply drinking water for the city. The study revealed that much of the recharge area for the ground water aquifers lie outside the Talomo- Lipadas watersheds. City Planning and Development Office, recognising the potential of the study to support governance, has since expanded the study to cover all of the Talomo Lipadas and is currently expanding the study to cover the rest of the City's watershed, with the aim of providing critical information to better understand the geophysical environment of the City's watersheds.

The geological, topographical and water resources data already collated through the expanded Terrain Analysis allows for deeper understanding of the current state of the watersheds. This in turn, as can be seen in the next section, enables more appropriate management strategies. As a result of the technical finding, integration of the various watersheds and introduction of science-backed policies and initiatives became priority for the local government water managers and policy makers.

\section{Using science to guide legal frameworks: Raising impacts}

Since clear legal and administrative pathways to protect water resources are seen as necessary before stakeholders will be willing to commit and agencies will be prepared to fund watershed related projects (Dyson et al., 2003), the Davao network then focused on enhancing good governance through policy development, enactment and implementation.

The terrain analysis presented a substantial leap forward in technical understanding of land form and topography and how this correlates to soil erosion. It provided the first scientifically backed recommendations by the city government to mitigate soil erosion and negative surface and ground water quality impacts. The recommendations were put in force through Executive Order 22 and included: the declaration of areas (34 $254 \mathrm{ha}$ ) as critical groundwater recharge zones and as conservation areas, and limiting land use of areas (12 240 ha) most susceptible to erosion and landslide. As the recommendations were disseminated, local actors began to question appropriate strategies how to implementation of EO 22. With a timely cross visit from the Murrumbidgee River basin, local councillors and advocates requested a review of the recommendations from the RCU of the HELP network. The review revealed large gaps in the understanding of the hydrogeology of the region and in understanding of the impacts of agriculture practices on water quality and quantity. While the landuse regulation was aimed at mitigating adverse agricultural impacts on the groundwater resources of the region, there are possible adverse impacts on the triple bottom line (social, economic, environmental) of already marginalised farming communities (Khan, 2006). The openness with which authors of the recommendations accepted the reviews was striking, and through consultations the Davao network moved forward to identify and develop implementation strategies that would both address the erosion issues and minimise impacts on marginal communities.

The most controversial challenge to the Davao HELP network to date was of the (then) proposed bill to ban aerial spraying in the city. Again the use of science, backed with extensive international experience from the HELP network, highlighted the water-related issues in different perspectives and thus encouraging sectors of different persuasions to listen and engage in sober discussions. Scientific views expressed in 2005 by Shahbaz Khan (2005), the HELP Regional Coordinator, on the (then) proposed bill to ban aerial spraying in the city were extensively covered by the media and widely sought by local leaders and legislators and the community. Khan emphasised the need for multi- faceted solutions, including investing in acceptable spraying methods without endangering freshwater or human health, the need for 
buffer zones and construction of filtration lagoons on banana plantations.

Inputs from the HELP network focused on raising awareness that the City can only ensure the long term health of the communities and ecosystems through integrated and comprehensive policies. Single focus ordinances tend to only delay or change the face of issues, and do not necessarily resolve the root causes of issue. In this case the ordinance focused on banning the technique of aerial spraying, and not the chemicals that are still in use. Once the ban was enacted councillors were quickly moving on the draft of a comprehensive water code to paving the way for more comprehensive management.

A comprehensive Water Code 2007 was later passed by the City Council at its first reading. The Water Code drew from HELP drafted Integrated Watershed Management Framework, integrates the Terrain Analysis study and supersedes EO 22. However, implementation of the Code has many challenges to overcome before the communities and end users start to feel the benefits.

\section{Recognising limitations and steps for a more effective network}

The aerial spraying issue is one of the most challenging conflicts which need to be transformed if IWRM is to be comprehensively implemented across the Davao watersheds. This issue cuts across ecological, social, economical, and political sectors and has divided stakeholders and communities. The issue has also highlighted the limitations of the Davao HELP network in its current voluntary and resource limited capacity.

In the process leading up to the council decision to ban aerial spraying, there were many negotiations (by the community, by councillors, by city executives) with the Philippine Banana Growers and Export Agency (PBGEA). Through the negotiation, common ground was identified on the crux issue but no agreement could be found. Advocates for the ban recommended a phase out period from 6 months to 5 years, but PBGEA's official position paper to the council stated a 25 -year phase-out (Esquillo, 08). With its dissatisfaction with the council decision PBGEA took the case to Regional Trial court which upheld the validity of the ordinance, and then to the Court of Appeals which granted preliminary injunction and as July 2008 had yet to give a ruling on the ordinance (Davao Today, 08).

While The HELP Network is in an ideal position to respond to this and other challenges, vis-à-vis the HELP framework and its ability to engage the plantations and other stakeholders, it has however to date lacked the capacity and resources to be a consistent leader for constructive engagement in this contentious arena. Recognising that the Davao HELP Network has its limitations, doable steps which would enhance the effectiveness of efforts have been identified and are considered valuable lessons for the Davao HELP Network and other basins with similar constraints.

\section{Institutionalising coordination and data management}

Clarifying what organisations are responsible for monitoring what, and identifying a single coordinating body where data can been centrally collected, managed and shared is a critical component for implementing of IWRM. This clarification is critical to sustain any move away from sectoral management. It also will help identify where private stakeholders, NGO's and communities can best assist the mandated agencies and better support the continued shift from conflict to collaboration between sectors.
In Davao this issue has been discussed and the roles are clear to those involved, but there continues to be no one reference point for accessing water management related information for those who do not know, be they NGOs, private business or individuals. A detailed review of the mandated roles needs to be conducted and made accessible to the public.

Issues of restricted mandated roles and budgets have been common stumbling blocks in the identification and agreement of a central body within the public sector and while the review of roles will help clarify who has what data it may not resolve who can be the central coordinating body. Through the initiatives of the Davao HELP Network it has become more obvious that this central coordinating body does not have to be a public institution. Civil non profit organisations are often less restricted and often better positioned to attract external funds. Once they have a formal agreement for the sharing of data with the local government bodies they can become the coordination point and data manager for IWRM.

The secretariat of the Davao HELP network, PCEEM Davao, has been identified as a possible non profit organisation which could fulfil such a role in Davao. The organisation has key skills for this role including: strong data management capabilities, proactive relationships with all sectors including government and agri-business. The vision and mission of the Secretariat is service oriented towards the dynamic participation of multi stakeholders in the governance of the Davao watersheds making them a long term and sustainable partner for the local government.

The Landcare watershed management process supported by multiple local and international organisations across Mindanao highlights a key feature in supporting better watershed management was through the landcare facilitators. The facilitators' role was deemed so critical that the bulk of program funds were directed towards supporting the facilitators (Metcalfe, 2004). To further enhance this, the Davao model can learn form an approach adopted in Ireland for implementation of the European Union's Water Framework Directive. The South Eastern River Basin District embedded an overall project coordinator in the local government to enable better data flow to the stakeholders who had joint the responsibilities for management water resources to comply with the Directive (SERBD, 2003). For the Davao Model a high-level public position could be created and embedded within the secretariat with the role of facilitating better coordinating with relevant government bodies, ensuring quality control of the data management and developing integrated reports for water managers and decision makers. Such role could also become a critical driver behind the Davao HELP network providing full time leadership and coordinating the IWRM across the 8 watersheds.

\section{Continual learning \& institutionalising user-driven experiences}

The UNDP Water Governance Facility highlights implementation as often being the weakest link in water governance. This paper has highlighted examples of policies, frameworks and programs ongoing in the Davao watersheds. As with the need for clarification of who is responsible for coordination and data management, it is an imperative that the Davao HELP network conduct a comprehensive and critical review of all the existing policies, frameworks and programs to distil out the most appropriate and successful approaches and to understand failures.

The individuals within the Davao HELP network are aware of many user-driven initiatives ranging from advocacy, to commu- 
nity water monitoring to implementing best practices in IWRM. Only a handful of the many actors and initiatives have been highlighted in this paper. There are many more groups coordinating at varying community levels, reporting to media or implementing innovative and resource efficient programs where the communities themselves are taking leadership in managing their water supplies and conserving localised catchment areas. However, without coherent documentation, old mistakes are repeated.

Without a structure for formally reporting to water managers and decision makers, these implementation successes will continue to fail to reach their full potential which can only be achieved through supportive government policies for replication and wide scale adoption.

Again the creation of the coordinating body is seen as a critical factor to enable basin-wide monitoring of various user driven projects. If formally monitored, the various projects can become in depth user driven implementation experiences that are invaluable for governments to monitor impacts and guide better land and water use policies and plans. Continued guidance from the global HELP UNESCO network will be critical to ensure that such 'user driven implementation experiences' are deemed important enough for local government to invest their budgets in such reviews, coordination, and monitoring initiatives.

\section{Better awareness, higher impact - Institutionalising capacities}

Through the HELP Davao network, technical awareness of the extent to which human activities have disturbed aquatic ecosystems has improved and a greater sense of urgency to address this situation has been established. However, large information gaps still exists about the freshwater needs and the critical roles they play in sustaining ecological services. There is less appreciation of concepts that groundwater needs to be managed to keep surface waters healthy, or that conditions can be managed to a large extent through knowledgeable management of river flows (Dyson et al., 2003).

For Davao, the network has prioritised the twinning research areas to address critical gaps inhibiting integrated management of water resources. A positive realisation for the Davao network is that many of the skills required to conduct the research themes are available within the pool of actors involved in the network. However, existing workloads and failure to institutionalise the need to address these gaps means that, as of yet, the skills remain untapped and the research questions unanswered. Other research areas such as prediction of environmental flows may require external support. With support under the twinning with the Murrumbidgee, the University of the Philippines Mindanao is exploring the possibility of offering formal programs to continue to develop local skills and capacities. The course would be tailored to help address the research questions being identified by local government and would look to provide incentives in conjunction with the local government bodies for water technicians, managers, and decision makers to join the course and assist professional and technical development within the public sector.

For sustainability of interventions, strategies need to be developed to focus energies on mainstreaming of the network and the HELP approach through the Department of the Environment and National Resources (DENR).

\section{From paper to action - enabling policy frameworks}

There are often significant delays between the issuance of an ordinance or code and the publication of the implementing rules and regulations (IRR), leaving a void after an ordinance is passed (Evans, 03). While the policy environment had progressed in Davao from fragmented legislation towards integrated governance, with the Water Code and EO 22 enacted, there remains a vacuum of how to implement the recommendations or who is responsible for what steps.

This vacuum creates a climate of inaction and the loss of positive momentum created by passionate stakeholders and advocates who supported the creation of ordinances. The result being witnessed in Davao is individual stakeholders returning to their ongoing work schedules and continuing to work in isolation. An ordinance is only the first step in a long process towards effecting change in end users practices. The critical next step is a clear timeframe for the drafting and implementing of IRRs. Such timeframes should be set at the time of enacting an ordinance and publicised. The IRR must as well identify a leading government body with the responsibility of developing partnerships with NGOs, academe, and private stakeholders for the implementation of the ordinance.

\section{Institutionalising responsibilities - realising cash flow}

It was highlighted above that a series of research areas were identified and technical teams were appointed to address the research questions; however, for the most part, these actions are still considered additional work and have not been subsumed into annual budgets and plans of the organisations.

The development of one research proposal which focused on the adoption of water systems management and low cost agricultural responsive technologies (Water SMART) proposed a three way partnership between a development organisation, local university and an international technical partner. The nature of the development partnership represented a substantial opportunity to bring both external funding and learning's to drive forward the Davao HELP network. Unfortunately the proposal was unsuccessfully but it was important for the network to take several learning's from the experience. Firstly the need to adopt a multi-donor approach for funding proposals, the need to ensure research is action orientated and includes a development focus which is user driven, but the most importantly is the need to integrate themes into local government plans.

Integration of such themes into local government plans is critical to demonstrate to external donors that the themes are the priority of both government and their communities. Once government have integrated components of the research theme into existing work schedules they can then support such development partnerships and use their existing budgets to help leverage external funds to address issues beyond the current capabilities of local government. Above all this, is the fact that investments in water contribute to wider development goals: not just for social, health and environmental reasons but also to directly generate economic growth that is, in many cases, effective in reaching the poor and that can transform the prospects of many of the marginalised regions (Soussan et al., 2006).'

Good governance as defined by the Poverty-Environment Partnership 'refers to a process that exists to promote popular participation in designing water and sanitation systems and where decisions about those systems are made (Soussan et al., 2006).' Integration of the Davao HELP network themes and the support of development partnerships are both actions that firmly demonstrate good governance. The IUCN also highlights that clear legal and administrative pathways are needed before agencies will commit resources (Dyson et al., 2003). For the HELP 
Davao network this means that individual actors of the network need to become the drivers of change within their own organisations, pushing for dynamic integration of policy frameworks and institutional plans for actions that are driven by understanding, research and utility for healthy and functioning watersheds.

\section{Conclusions}

The Davao network has demonstrated a method of how to apply the HELP principles with limited resources. With involvement of a broad range of interest groups, ownership and active participation was achieved.

Using sound science the network has become a practical platform where competing stakeholders can debate possible solutions and build collaboration. It has also become a driver for good governance. The changes were repeatedly demonstrated through the attitudes and behaviour of stakeholders. However, data and technical capabilities still remain major limiting factors in progressing IWRM in Davao.

A major limitation of the Davao network and the change it has effected is obvious in the ongoing community conflicts over aerial spraying. Still the Davao Network has the respect of stakeholders from all sectors, and is continuing to function as a learning alliance, enhancing capacities, understanding and relationships. This position coupled with the HELP framework places the Davao HELP network in an ideal position to respond to this challenge. However, renewed local leadership and implementation of twinning research areas are both critical steps to enable the HELP network to respond to such challenges.

Institutionalising of the twinning research themes will both demonstrate good governance and place the HELP Davao network in a stronger position to attract external funds tofurther address the limitations of the network. The current supportive local government presents an ideal time for tackling of cumbersome and technical issues, including the streamlining of legislation and formation of a central coordination body.

The practical user driven structure also positions the HELP Davao network in a desirable niche and minority position when compared in the global HELP community where 'mostly project teams [local basin networks] were from universities or research institutions, with only a few members from government agencies. This user driven approach is a key strength of the Davao HELP network and will continue to be critical in ensuring support, utility and sustainability of interventions.

While limited resources is a controlling factor in the extent and pace at which change can occur the HELP Davao network has demonstrated that knowledge is empowering and change occurs not despite of budgets but because of understanding and a clear expressed need for change by the end users. The HELP Davao network has linked and empowered multiple actors, from the field to the law makers and change is occurring.

\section{Acknowledgements}

The authors wish to acknowledge all the participating actors in the HELP Davao network including:

- The national government represented by Department of Environment and Natural Resources, Department of Agriculture, National Economic and Development Authority
- The city government of Davao represented by City Planning and Development Coordination Office, City Council Chair for the Environment, City Environment and Natural Resources

- The academic community such as University of the Philippines, Mindanao, Philippines Science High School Mindanao

- Non-government organisations local and international including PCEEM, CRS and KFI.

- Private (and semi private) sectors Davao City Water District, Philippine Banana Growers Export Association (PBGEA)

- Local communities, across the watersheds, at the core of the network.

\section{References}

BAIS G (2006) Personal communication. Executive Director. PCEEM, Davao City, Philippines.

CATACUTAN D (2006) Economic Growth and Watershed Management: Drivers of Research and Development Innovations. World Agroforestry Centre (ICRAF-Philippines).

CPDO (2000) Comprehensive Land Use Plan of Davao City. City Planning and Development Office.

CRUZ MC and CRUZ MCJ (1990) 'Population pressure and deforestation in the Philippines'. ASEAN Econ. Bull. 7 (2) 200-212.

DYSON M, BERGKAMP G and SCANLON J (eds.) (2003) Flow. The Essentials of Environmental Flows. IUCN, Gland, Switzerland and Cambridge, UK. xiv +118 pp.

DAVAO RIVER SITUATIONAL REPORT (UP Mindanao, 1998) Asian Geodyne Study, Aquifer Study (Consultancy to DCWD, 1999) and the Hydrological Monitoring Conditions and Recommendations.

DAVAO TODAY (2008) http://davaotoday.com/2008/08/04/ca-hit-forfailure-to-decide-on-aerial-spraying/

EVANS D (2002) Davao River Management Plan. DRCCC, Philippines.

EVANS D (2003) Davao River Primer. IDIS and VSO, Philippines.

EVANS D (2003) Hydrological Monitoring Conditions and Recommendations, DRCCC, Philippines.

ESQUILLO LJ (2008) Personal Communications. Executive Directors, IDIS, Davao City, Philippines.

GAMBOA R (2005) Health Report: TL, PCEEM DavaoDavao City, Philippines.

GLASGOW GJ, McCARTHY D and HEARNE D (2003) South Eastern River Basin District Legislative Review, SERBD. Ireland.

HEARNE D (2004) Workshop Proceedings Identification of Key Action Areas for Twinning Objectives. Davao HELP Network, Waterfront Davao, Philippines .

KHAN S (2005) Regional Coordinator, UNESCO IHP-HELP and Director: International Centre of Water for Food Security, Charles Sturt University, Australia. Since 2008 Global Coordinator HELP, Natural Sciences Sector, UNESCO, Paris, France.

MEDALYE J and KUNDELL J (2008) Water governance. In: Encyclopedia of Earth. Cutler J (ed.). Cleveland (Washington, D.C. Environmental Information Coalition, National Council for Science and the Environment).

METCALFE J (2004) Landcare in the Philippines - Stories of People and Places, ACIAR, Australia.

SHEPHERD G (2004) The Ecosystems Approach: Five Steps to Implementation. IUCN, Gland, Switzerland and Cambridge, UK. Vi +30 pp.

TIU R (2005) Davao: Reconstructing History from Text and Memory. Davao City. Research and Publication Office. Ateneo de Davao University and Mindanao Coalition of Development NGOs, Philippines.

UNDP (2006) Improving Water Governance Implementation, UNDP Water Governance Facility, www.watergovernance.org/ 